\title{
On the ecophysiology of the sponge Halichondria panicea in Kiel Bight. I. Substrate specificity, growth and reproduction
}

\author{
Dagmar Barthel \\ Institut für Meereskunde, Abteilung Meeresbotanik, Düsternbrooker Weg 20, D-2300 Kiel 1, Federal Republic of Germany
}

\begin{abstract}
Between December 1983 and April 1985, field experiments and laboratory observations on Halichondria panicea were performed in the 'Hausgarten' area at Boknis Eck, Kiel Bight. The sponge population was sampled regularly by dredging and scuba diving. Field growth experiments were conducted at the same time. Phyllophora sp. and Phycodrys sp. were the preferred substrate algae, while Delesseria sanguinea and filamentous fine algae served as substrate only occasionally. A variety of inorganic and organic hard substrates was also found to be accepted by sponges. Growth of $H$. panicea was observed between March and July. Growth rates seemed strongly dependent on temperature, less correlated with food availability. The most vigorous growth occurred in May and June. After July, a strong decline in mean weight of the individually marked specimens resulted in negative growth rates until the end of September. During late fall and winter, no changes in mean individual weight were observed. Considerable changes in biochemical composition (condition index and protein, lipid and glycogen content) and appearance of young colonies of $H$. panicea in early fall indicate that the main reproductive activity occurs in August and September. As this is the time of greatest weight loss in adults, it can be inferred that adult $H$. panicea degenerate and disintegrate after reproduction.
\end{abstract}

\section{INTRODUCTION}

Despite the fact that sponges are important members of many shallow water marine benthic communities, comparatively little and scattered information on their ecophysiology and ecology is available. This surprising gap of knowledge exists partly because marine sponges are not easy subjects to study. The difficulties include, but are not limited to, lack of methods suitable for long term maintenance of most sponges in the laboratory (Fell 1967, Kinne 1977), and problems with age determination and monitoring of natural populations (Ayling 1980). Nonetheless, studies on the population dynamics of marine sponges have been conducted by Reiswig (1973) on subtidal Jamaican sponges and by Fell \& Lewandrowski (1981) on a species of estuarine sponge in a New England eelgrass community.

Halichondria panicea Pallas, which grows abundantly in the red algae zone of the Western Baltic Sea and in many locations in the North Sea, belongs to those species hitherto more or less neglected. This is all the more regretable as data concerning this very abundant organism are lacking in modeling energy and matter transfer processes in Kiel Bight. Theede (1981) shows $H$. panicea to account for at least $15 \%$ of the macrobenthos in the red algae zone of the 'Hausgarten' area, but higher densities can probably be reached in other years and areas.

In this study, an attempt is undertaken to elucidate some important basic aspects of the biology of Halichondria panicea, i.e. substrate specificity, growth, and reproduction. As early as 1949, Burton described how colonies of Halichondria living on rocks merged, fragmented and constantly changed their whole shape. Thus, all growth and production concepts based on the existence of recognizable individuals could not be used for this purpose and a different experimental approach, i.e. that of cage experiments, was applied.

Further important questions concerning energy budget, biomass values and integration of Halichondria panicea into the Kiel Bight ecosystem will be dealt with in a subsequent publication. 


\section{MATERIAL AND METHODS}

Area of investigation. All investigations were performed on the sponge population in the so-called 'Hausgarten' area (e.g. Smetacek et al. 1984), located in Kiel Bight near the entrance to Eckernförde Bight. Here, the red algae constituting the main substrate for Halichondria panicea grow most abundantly on glacial lag sediment (rocks up to boulder size) and coarse sand between 2 and $10 \mathrm{~m}$ water depth. Sampling took place between December 1983 and April 1985.

Growth experiments. Sponge material was usually collected by divers and occasionally by dredging. Even in slow dredging, sponges usually get compressed and upon coming on deck, the normally water-filled canal system drains and fills with air, producing an embolism-like situation. Thus, sponges floating at the surface of the transport containers were carefully sorted out. Within a day after collection, clean pieces of sponge were cut off the main colony and were inspected for algal remnants or other non-sponge material; if such materials were present and could not be removed, the sponge was discarded. Suitable pieces were suspended from nylon threads, following a procedure developed for laboratory culture of Halichondria panicea (Barthel \& Theede 1986). Then the specimen volume was measured to the nearest $0.1 \mathrm{ml}$ and the threads were attached to a small metal wire cage $20 \times$ $30 \times 8 \mathrm{~cm}$ ) submerged in well-aerated seawater. The attachment site of each sponge was marked individually. The following day, the cages were deployed by divers in the 'Hausgarten' in $10 \mathrm{~m}$ water depth in the middle of the field population from which the sponges had been collected (Fig. 1). The site was marked by a surface buoy. Volume, drip-dry wet weight (WW), dry weight (DW) and ash-free dry weight (AFDW) of 10 to 20 individuals of the same population were determined and regression lines between volume and weight parameters were calculated. As AFDW turned out to be the most reliable parameter, all growth and biomass changes are expressed as AFDW

At monthly intervals, about 10 to 20 individuals of the experimental cage population were recovered by divers and brought back to the laboratory for growth rate measurements. Along with this, the surrounding undisturbed sponge population was sampled for determination of biochemical composition and also for general observation of seasonal changes in the natural sponge population.

Volume and weight parameters. Specimen volume was determined by submerging the sponge attached to the nylon thread into a graded glass cylinder filled with cooled habitat water. For determination of WW, sponges were left to drain on 'Kleenex' tissue for a few minutes. Larger specimens were divided into 2 or more pieces in order to guarantee complete and even drainage. DW and AFDW were determined after lyophilization and complete drying for $24 \mathrm{~h}$ (DW) with subsequent overnight ashing in a muffle furnace at $550^{\circ} \mathrm{C}$ (AFDW). Complete drying at $100^{\circ} \mathrm{C}$ is necessary to avoid errors based on residual water content of the spicules (Paine 1964).

Biochemical parameters. Elvin (1979) clearly demonstrated the relation between gross biochemical composition and reproductive cycle in the sponge Haliclona permollis. This method was therefore selected to gain insight into the reproductive cycle of $H$. panicea in the Western Baltic. The relation of organic to inorganic substance was defined as condition index. For each date, at least 5 subsamples of sponge material were analyzed.

Total protein content was determined by the Biuret method (Merck test kit 3327). Samples of $100 \mathrm{mg}$ of lyophilized, complete-dried and ground sponge tissue were treated with $1 \mathrm{ml}$ of $96 \%$ ethanol for $10 \mathrm{~min}$. After centrifugation (10 min, $5000 \mathrm{rpm}$ ) and discarding

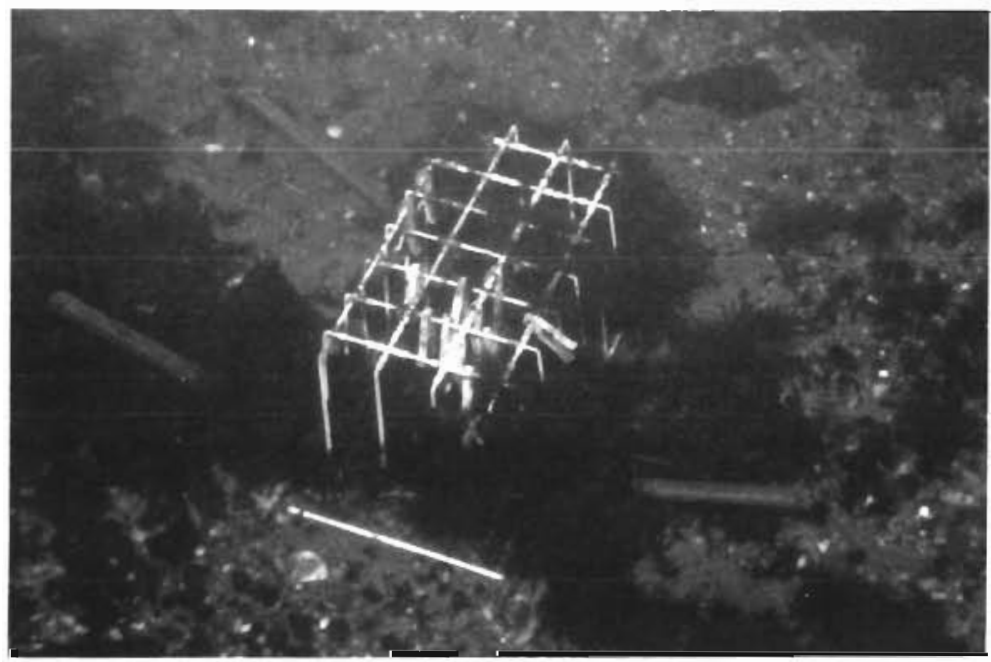

Fig. 1 Metal wire cage for field growth experiments at the study site, Boknıs Eck, $10 \mathrm{~m}$. Individually marked sponges were fastened to the cage by nylon threads suspended from numbered clothes pegs; the cage was anchored to the bottom by tent pegs 
of the supernatant, the procedure was repeated with diethylether instead of ethanol. Afterwards, the sediment was resuspended in $3 \mathrm{ml} 3 \% \mathrm{NaOH}$ and left in a mixing table overnight. After centrifugation the next morning the determination was carried out on two $100 \mu$ aliquots of the sample with BSA serving as reference. With this method, both skeletal protein (spongin) and cellular protein are included in the protein determination and it is not possible to quantify the share of either fraction. Thus, wherever 'total protein' is referred to in the text, it must be kept in mind that it includes both metabolically active and more or less inactive substances.

Lipid content was determined by the phosphovanillin method (Zöllner \& Kirsch 1962). Ten mg of lyophilized ground sponge material was mixed with

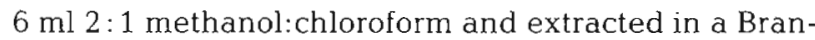
son Sonifier cell disruptor for $5 \mathrm{~min}$. Two $\mathrm{ml} 0.2 \%$ $\mathrm{CaCl}_{2}$ solution was added to the samples. After centrifugation (15 min), the upper fraction containing the methanol was removed and $200 \mu \mathrm{l}$ of the chloroform fraction containing the lipids was transferred to a clean glass tube, dried at $40^{\circ} \mathrm{C}$ in a vacuum desiccator, mixed with $1.6 \mathrm{ml}$ conc. $\mathrm{H}_{2} \mathrm{SO}_{4}$ and incubated at $90^{\circ} \mathrm{C}$ for $30 \mathrm{~min}$. After cooling to room temperature, $4 \mathrm{ml}$ phosphovanillin reagent $\left(4: 1 \quad \mathrm{H}_{3} \mathrm{PO}_{4}: 0.6 \%\right.$ vanillin solution) were added and the mixture was left to react for $30 \mathrm{~min}$. Extinction was measured at $530 \mathrm{~nm}$ with lanolic acid as reference.

Glycogen content was measured with the anthrone reaction (van Handel 1965). Fifty mg of lyophilized ground sponge tissue was dissolved in $0.5 \mathrm{ml} 30 \%$ $\mathrm{KOH}$, heated for $30 \mathrm{~min}$ to $100^{\circ} \mathrm{C}$ and cooled to room temperature. Then, $50 \mu$ saturated $\mathrm{Na}_{2} \mathrm{SO}_{4}$ solution and $2 \mathrm{ml} 96 \%$ ethanol were added. For precipitation of glycogen, the mixture was left in a refrigerator overnight. After centrifugation (15 min, $5000 \mathrm{rpm})$ the supernatant was discarded and the sediment was redissolved in $1 \mathrm{ml} 15 \%$ TCA and centrifuged again. The protein-free supernatant was transferred into a clean glass tube and a few grains of $\mathrm{KCl}$ and $5 \mathrm{ml} 96 \%$ ethanol were added for renewed precipitation of glycogen. Again precipitation was enhanced by leaving the sample in the refrigerator for 1 night. After centrifugation, the supernatant was discarded and the sediment was redissolved in $5 \mathrm{ml}$ distilled water. One $\mathrm{ml}$ of this extract and $2 \mathrm{ml}$ anthrone reagent $(2 \mathrm{mg}$ anthrone in $1 \mathrm{ml}$ conc. $\mathrm{H}_{2} \mathrm{SO}_{4}$ ) were mixed in an ice bath. After 20 min heating to $90^{\circ} \mathrm{C}$, extinction was measured at $620 \mathrm{~nm}$ with commercially available glycogen serving as reference.

As only small amounts of really clean sponge material could be obtained at the beginning of the investigation in winter 1983/84, no subsamples were taken and the whole available sponge material was pooled.
In order to determine the variability in the component levels, a large number of sponges were collected at Boknis Eck in March 1985 and 12 parallel samples were analyzed. Standard deviation was about $10 \%$ for total protein and lipid content and about $33 \%$ for glycogen. This agrees well with the variability found by Elvin (1979) in a population of Haliclona permollis.

\section{RESULTS}

\section{Substrate specifity}

Numerous observations showed that the 3 red algae genera growing most abundantly in the area, i.e. Phyllophora sp., Phycodrys sp. and Delesseria sanguinea, are not covered with sponges evenly. While Phyllophora and Phycodrys usually bear large amounts of sponges, $D$. sanguinea serves as substrate only very occasionally. Sponge colonies generally were found on any part of the former 2 algae, but mostly on the tips. The few colonies found on $D$. sanguinea were usually located on the stems, not on the leaves. Small filamentous algae such as Ahnfeltia plicata or Ceramium rubrum which can be found in abundance during the summer did not serve as primary substrates, but were partly overgrown by $H$. panicea in summer. Inorganic and other non-living substrates were also utilized as substrate by Halichondria panicea.

\section{Growth of Halichondria panicea in the field}

In looking for a suitable method to measure sponge growth, the volume/AFDW correlation gave the best results (Fig. 2). Volume and WW or DW could not be correlated with the same efficiency, which is probably due to changing amounts of water and spicules respectively in the sponges. As the physiology of the sponges changes with season, the slope of the regression line also varies with season and has to be determined anew each time a growth experiment is started.

The field growth experiment was started in March 1984. The first cage with about 100 sponges was deployed at Boknis Eck in $10 \mathrm{~m}$ water depth. Later, cages were also anchored in shallower parts of the area, but the surface buoys and their $25 \mathrm{~kg}$ lead weights were removed by unknown persons a few days after deployment and the cages could not be recovered in spite of an intensive search. Surface markers were also lost at the $10 \mathrm{~m}$ station in July 1984; the cage could be recovered, but only in September, thus growth data for August are lacking. Severe ice conditions in the area from beginning of January to April 1985 prevented sampling of the cage population and again 


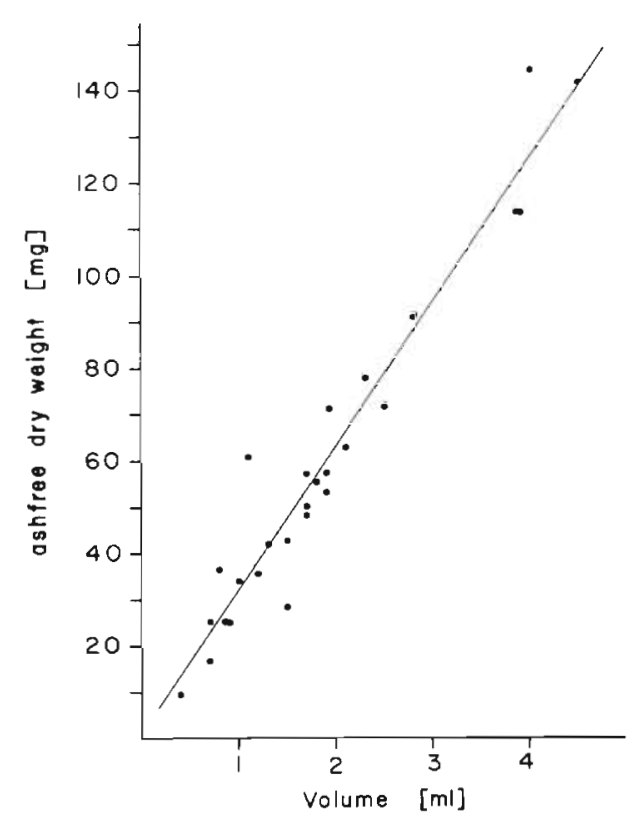

Fig. 2. Halichondria panicea. Correlation between individual volume and content of organic substance, expressed as ashfree dry weight. Boknis Eck, Mar 1984. Equation: $y=1+$ $30.99 \mathrm{x} ; \mathrm{n}=26, \mathrm{r}=0.965$

destroyed the site markers; this time the cages could not be found again

Growth of Halichondria panicea at the Boknis Eck station showed a strong seasonal trend (Fig. 3). In spring, growth rates were very low, even during the spring phytoplankton bloom in March/April (black bar in Fig. 3). Growth increased towards summer and reached a maximum in June. At the end of June/

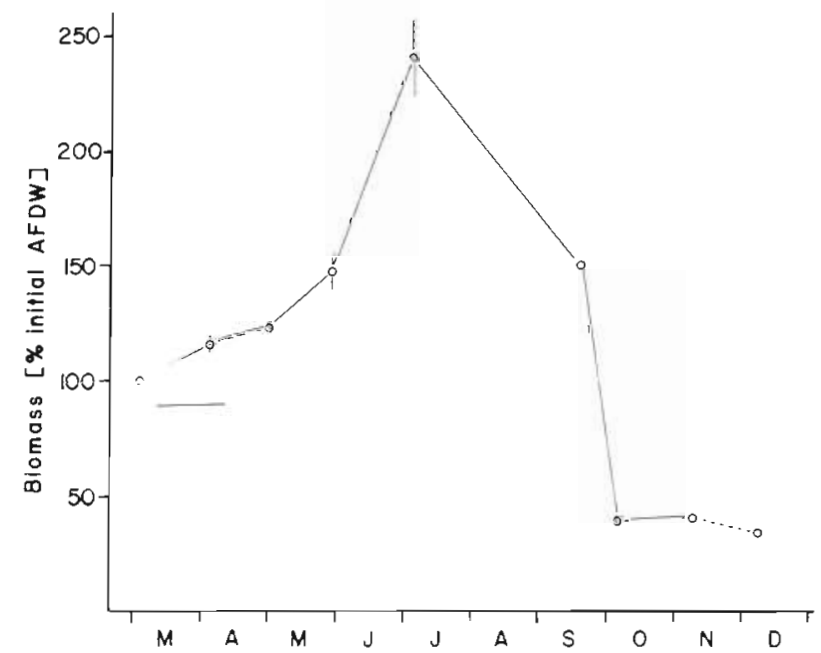

Fig. 3. Halichondria panicea. Field growth experiment at Boknis Eck, $10 \mathrm{~m}, 1984$. As individual size at the beginning of the experiment varied, growth is expressed as increase in mean individual biomass. Means and standard deviation of means from 7 to 15 individuals. Dotted line: results from a second cage deployed in Nov 1984; bar: time of phytoplankton spring bloom beginning of July, the highest mean individual weights were reached. After that, biomass (Fig. 3) showed a very drastic decrease: growth stopped and in late summer sponges exhibited negative growth, i.e. they shrank. From March to October 1984, the sponges in the cage population did not gain weight, they even suffered a net loss of $50 \%$ of the mean individual content of organic substance compared to the beginning of the experiment in March.

Examination of the temperature regime in the area during the period of investigation (Fig. 4) shows that the beginning of more intense growth coincided with rising temperatures, which indicates growth intensity to be at least partly dependent on ambient temperature. Nevertheless, it was not necessarily temperature that was responsible for the very drastic weight and size decrease in the cage population between July and October; close inspection of the Halichondria panicea individuals after recovering them gave indications of changing physiological condition during the investigation period.

In the first weeks after the beginning of the experiment, sponges grew as clean individuals, forming compact, lumpy colonies. In early summer, a number of other organisms settled on them, the polychaete Polydora ciliata being the most often encountered species. Later, the individual sponges started to merge with each other and formed larger aggregates. While at first former individuals were still discernible and separable, in September only a bulk evaluation of aggregates was possible. Although already smaller than in July, the sponges had a healthy appearance with smooth surface and without any visible sign of necrosis or any other form of pathological change. By this time (September), body shape had changed from a more compact to a thin and stringy form. At the same

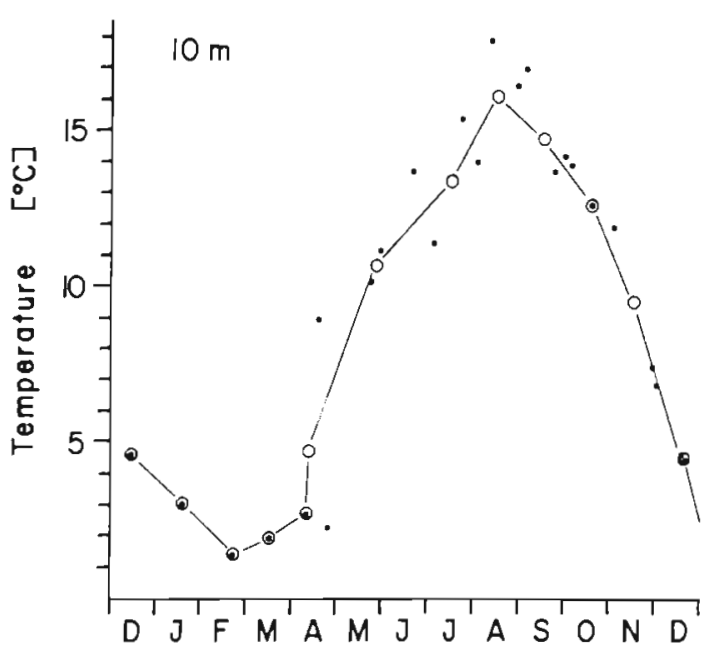

Fig. 4. Temperature at Boknis Eck, $10 \mathrm{~m}$. (๑) single measurements; (O) monthly means calculated from single measurements. Weigelt \& Seifert unpubl. data 
time, small freshly settled sponge colonies started to appear in the habitat, on the red algae as well as on the metal and plastic material of the cages. This seemed to indicate that the changes observed in the sponges might well be the result of adult degeneration after reproduction. As will be shown, results of the biochemical analysis strengthen this hypothesis.

\section{Biochemical composition}

At each sampling date, particularly clean and unfouled speciments of Halichondria panicea were lyophilized, completely dried at $100^{\circ} \mathrm{C}$, ground and kept in a desiccator until analysis. After completion of the field observations, ash content and protein, lipid and glycogen content of the samples were determined.

The condition index of Halichondria panicea (Fig. 5) underwent considerable variation throughout the year. In winter, the share of organic substance in the DW was quite low, as is documented by an index below 0.5 . During the time of active growth between March and June, the value rose gradually until a first peak was reached at the end of June. Exactly at the time when sponges began to decrease in size - a few weeks before the appearance of the newly settled colonies - the condition index exhibited a clear minimum; this was followed by a recovery of the condition index before the share of organic matter eventually decreased in late fall. That the condition index summer minimum coincided with the biomass reduction of the experimental sponge population seems to indicate a release of larvae, which consist mainly of organic substance and do not bear more than a few spicules (Wilson 1935). According to Elvin (1979), this event should be mirrored in the biochemical composition of $H$. panicea. Indeed, the biochemical composition of $H$. panicea varied strongly during the seasons (Fig. 6).

The components total protein, lipid and glycogen

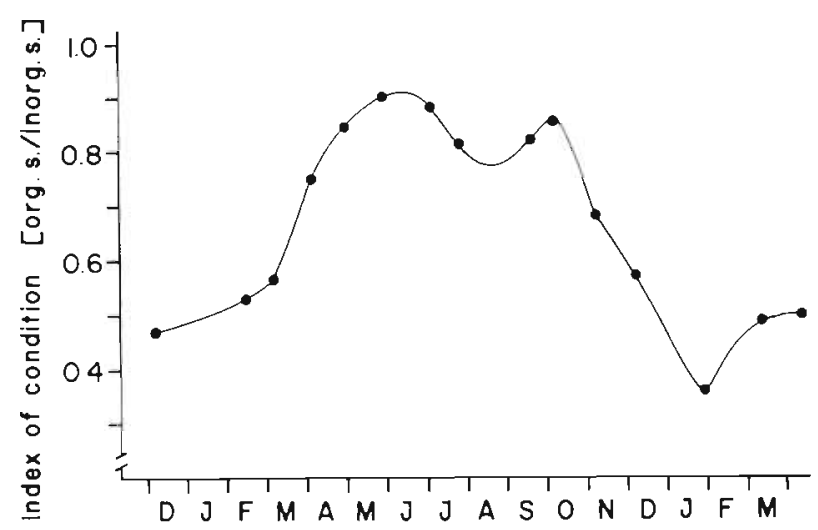

Fig. 5. Halichondria panicea. Development of condition index between Dec 1983 and Apr 1985 at Boknis Eck, $10 \mathrm{~m}$ represented very different shares in the total organic substance. Total protein, i.e. skeletal and active protein, constituted the largest share, 400 to $800 \mathrm{mg}$ (g AFDW) $^{-1}$, followed by the lipid fraction (about 80 to $100 \mathrm{mg}(\mathrm{g} \mathrm{AFDW})^{-1}$. Glycogen was present only in minimal amounts (10 to $30 \mathrm{mg}\left(\mathrm{g} \mathrm{AFDW}^{-1}\right)$. Slightly higher amounts of glycogen were observed solely during times of comparatively high phytoplankton concentrations in the water, i.e. during the spring and fall phytoplankton blooms (SB and FB in Fig. 6). Glycogen apparently is not accumulated in larger amounts. Lipid and protein content also varied considerably with season. In February and March, lipid content at first increased strongly, but decreased toward the end of April. This sequence is not found in the protein curve: protein increased during the depletion in lipids; a plateau was reached in May/June; at the same time, lipid content decreased again, and a few weeks later total protein content showed a similar development. Nevertheless, neither protein nor lipid content reached values as low as in the winter. In August and October,

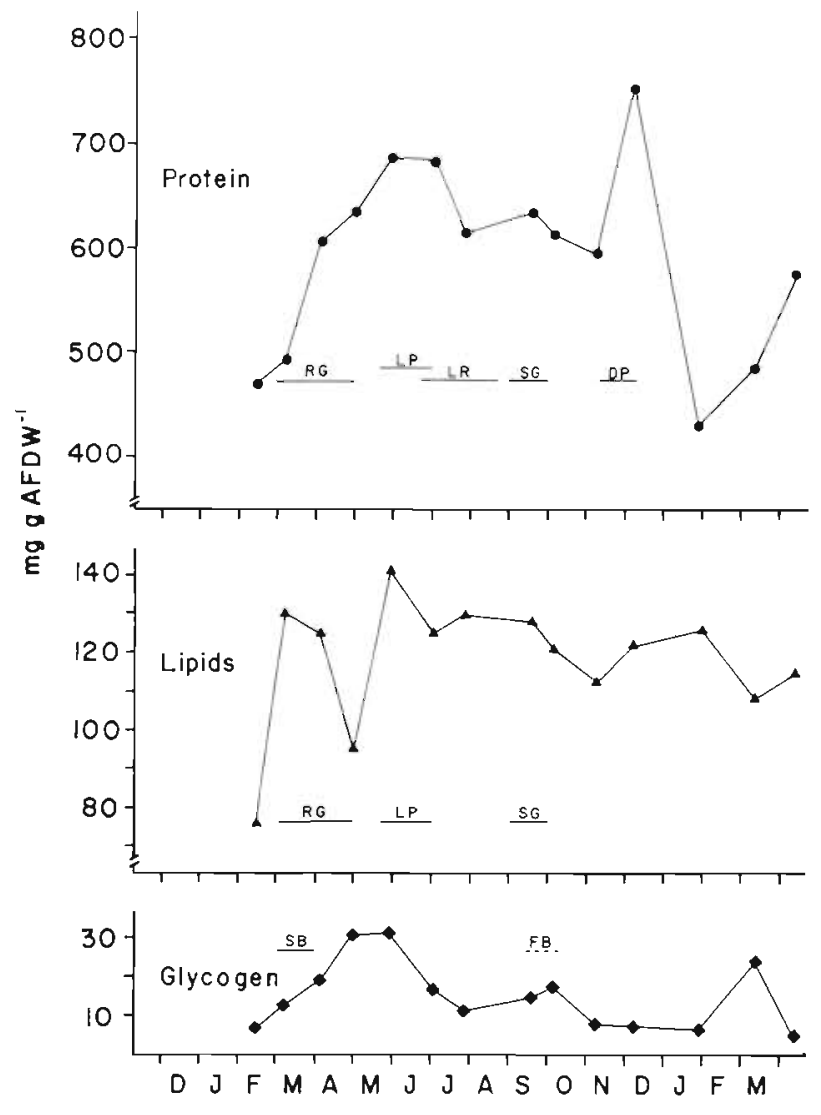

Fig. 6. Halichondria panicea. Development of biochemical composition between Dec 1983 and Apr 1985. Pooled samples. RG: reproductive growth; LP: larval production; LR: larval release; SG: somatic growth; DP: degeneration phase; SB: phytoplankton spring bloom (sediment trap data from Pollehne pers. comm.); FB: probable occurrence of fall bloom, no direct data available. Details see text 
total protein and lipid contents showed only comparatively little variation.

The most interesting feature to be observed is the peak total protein content of about $780 \mathrm{mg} \mathrm{P}$ (g AFDW) ${ }^{-1}$ in early December. In January 1985, severe ice conditions unfortunately prevented sampling and in February, the lowest total protein content during the investigation period was reached. The development in the following months was similar to levels observed in the previous winter.

\section{DISCUSSION}

As can be seen from the results of the correlation of volume and AFDW in Halichondria panicea (Fig. 2), it is possible to determine the organic content of sponges by relating it to volume. This approach, which was also chosen by Dayton et al. (1974) for their work on Antarctic sponges, provides a good basis for the determination of sponge growth, as volume determination does not harm the sponges and prevents errors stemming from varying density and water content of sponges of the same volume. Whether this correlation also holds for other sponge species cannot be said at present.

Results of the growth experiments show that positive growth of Halichondria panicea in the Western Baltic takes place in spring and early summer only, while sponges shrink in size later in the year. Growth and shrinkage are probably ruled by temperature, food availability and life cycle of the species, with varying degrees of importance of each factor at different times of the year. As active growth does not start at low temperatures even when food is abundant during the phytoplankton spring bloom, temperature seems to be the determining factor for growth at this time of the year. This result is consistent with findings on other sponge species. Elvin (1976) found that Haliclona permollis exhibited more intense growth with rising temperature. An unidentified species of the genus Halichondria at the Connecticut coast also started to growth with increasing temperatures in spring, while a state of dormancy prevailed in winter (Fell \& Lewandrowski 1981). In experiments conducted by Benfey \& Reiswig (1982) growth of gemmules of the freshwater sponge Ephydatia mulleri increased at higher temperatures and could be stopped completely by reducing temperatures to below $5^{\circ} \mathrm{C}$. Similar observations were made by Storr (1976) on a field population of Hippospongia lachne.

In cases where adverse effects of high temperature on growth of sponges were documented, inhibiting temperatures were always maximum temperatures in the corresponding habitat and might well represent the upper temperature limit of the species in question.
Johnson (1979) found for Clathrina coriacea and $C$. blanca that most vigorous growth of these species occurred at lower habitat temperatures. Similar results have been found for a number of other species (Coe 1932, Coe \& Allan 1937, Wells et al. 1964). The investigations of Wells and coworkers dealt with a habitat (North Carolina, USA) in which temperatures vary between $5^{\circ} \mathrm{C}$ in December and about $30^{\circ} \mathrm{C}$ in August, and it is interesting to note that a species closely related to Halichondria panicea, $H$. bowerbanki, degenerates completely in summer after having reproduced. Thus, besides unfavourable temperatures, degeneration of adults after reproduction is a possible cause for the observed weight and size decrease.

From the biochemical data it is clear that the beginning of the shrinking process in the experimental population is accompanied by decreases in the share of organic matter in dry weight and in the relative content of total protein. According to the scheme proposed by Elvin (1979) for Haliclona permollis, this drop indicates that the release of sponge larvae begins in August. As small colonies are found in the habitat a few weeks later, it seems very probable that the adults degenerate after reproduction. This effect is known from freshwater sponges (Kilian 1952) but also from other marine species (e.g. Wells et al. 1964). If we relate the drop in total protein and the loss of organic substance in July/August with larval release (Fig. 6: LR), we can also relate previous biochemical changes to reproductive processes. The primary increase in lipids in February/March would mark production of nurse cells. The lipids accumulated in the nurse cells are utilized during oogenesis and spermatogenesis which leads to the observed increase in protein content a short time later (Fig. 6: RG). (For a general description of the processes involved see Fell [1974].) After fertilization, the development of larvae as an energyconsuming process causes a renewed drop in lipids (Fig. 6: LP). As proteins are only restructured but not accumulated during larval formation, the total protein content curve reaches a plateau before larvae are finally released (Fig. 6: LR). After this, the adult sponges degenerate and shrink in size. The final peak in the total protein content curve is observed at a time when the condition index steadily decreases. This indicates a continuous loss of active plasma substance (Fig. 6: DP), until most of the remaining organic substance consists of skeletal protein (spongin), which eventually is broken down as well.

The interpretation of the biochemical changes as a whole would reveal an even clearer picture if a differentiation between plasma and skeletal protein could have been made at the time of investigation. Unfortunately, no method of effecting a complete and quantitative separation of cellular and skeletal materi- 
al was available, so, up to now, we do not know for certain whether we are looking at changes in the live protein only, or if further processes are masked by variations in skeletal and cellular protein not discernible by simply assaying total protein. Meanwhile, however, a separation method has been found and a study dealing with this aspect is currently under way.

The timing of larval release in early fall agrees well with data available for Halichondria panicea from other localities: Burton (1949) reasons early fall to be the time of larval swarming along the Devon coast of S.W. England and Lévi (1956) names June for the Mediterranean. Bergquist \& Sinclair (1973) observed settling of $H$. panicea larvae in New Zealand during December and January, the summer there.

The time of larval release to some extent explains why small filamentous algae do not serve as substrate for Halichondria panicea: during fall, these algae do not have large thalli; the small reproductive units of these species settle at about the same time as the sponge larvae, spend winter in a resting condition and start to grow in spring, long after the young sponge colonies have established. Why a perennial species like Delesseria sanguinea is not utilized as substrate remains unclear, but the mechanical effect of a mucuscovered algal surface, as has been documented for Laminaria (Remane 1940), might play a role.

In the context of lack of nutrition as a possible reason for the biomass decline in Halichondria panicea in summer, it is interesting to note the small amount of glycogen present in the sponges at all times of the year. As in some other species glycogen does not seem to serve as a major energy store (Giese 1966, Elvin 1979). The lipids accumulated early in the year are utilized to fuel reproduction. Thus, it can be concluded that growth of $H$. panicea in the Western Baltic Sea is mainly sustained by the regenerated primary production in summer. As biomass of planktonic algae in Kiel Bight usually rises slightly during the summer (Smetacek et al. 1984), and sponges can also digest bacteria very effectively (Pourbaix 1931, 1932, Rasmont 1963, Claus et al. 1967, Madri et al. 1967), lack of nutrition can probably be ruled out. Additionally, $H$. panicea very likely profits from symbiotic algae present in the sponge tissue (Eimhjellen 1967, Christensen 1985). Muscatine et al. (1967) showed that algae symbiotic with a ciliate, a sponge and a hydra excreted up to $86.7 \%$ of their total photosynthate as maltose or glucose, while related free-living strains liberated much smaller amounts (up to $7.6 \%$ ) and most of it as glycolic acid, none as maltose or glucose. The extent to which algae contribute to sponge nutrition will be largely dependent on general light regime and on habitat depth; up to now, no quantification of this process has been attempted.
The degree to which organic matter (DOM) is utilized has not yet been quantified exactly. While Puitter (1914) suggested that the sponge Suberites massa could subsist on dissolved organic substances alone, and certainly overrates the importance of DOM, dissolved organic substances were shown to be incorporated by sponges (Pourbaix 1932, Schmidt 1970, Weissenfels 1976, Ferguson 1982). On the basis of oxygen consumption measurements and incubation with labeled amino acids in natural concentrations, Ferguson (1982) calculated amino acid uptake to account for 3.9 to $9.2 \%$ of total energy requirement of the sponge Cliona celata.

The question remains whether the growth characteristics measured in the cage experiments are comparable to the growth activities of the natural population in the Western Baltic. From parallel biomass measurements in the same location (Barthel unpubl.), it can be seen that growth and biomass curves are more or less identical, except for the fact that the biomass decrease in the natural population occurs somewhat later. This circumstance is masked in the growth experiments, as sampling in August was prevented through the loss of the station surface markers. Growth rates measured in the Western Baltic do not represent the full potential of the species; Halichondria panicea situated in the marine environment of the North Sea have been found to posess higher growth rates (Barthel unpubl.).

Ecologically, Halichondria panicea can probably be characterized as 'sessile zoobenthos', since the sponge removes part of the regenerated primary production in summer during the time of its strongest growth and releases nutrients into the euphotic zone, thus stabilizing the regenerative cycle and diminishing sedimentation of phytoplankton to the benthic community. Questions pertaining to this complex will be dealt with in a subsequent publication.

Acknowledgements. This publication contains parts of the author's Ph. D. thesis, during which she was generously supported by a fellowship of the 'Studienstiftung des Deutschen Volkes'. I thank Professor Dr. H. Theede, whose advice and helpful discussions accompanied the study during the whole time. Thanks are also due to the members of the Scientific Diving Group of Kiel University; without their help, sampling would not have been possible. Last but not least I am grateful to Professor Dr. S. A. Gerlach, whose valuable criticism helped to improve the manuscript.

\section{LITERATURE CITED}

Ayling, A. L. (1980). Patterns of sexuality, asexual reproduction and recruitment in some subtidal marine Demospongiae. Biol. Bull. mar. biol. Lab., Woods Hole 158: 271-282

Barthel, D., Theede, H. (1986). A new method for the labora- 
tory culture of sponges and its application to experimental studies. Ophelia (in press)

Benfey, T J., Reiswig, H. M. (1982). Temeprature, pH and photoperiod effects upon gemmule hatching in the freshwater sponge, Ephydatia mülleri (Porifera, Spongillidae). J. exp. Zool. 221: 13-21

Bergquist, P. R., Sinclair, M. E. (1973). Seasonal variation in settlement and spiculation of sponge larvae. Mar. Bıl. 20: 35-44

Burton, M. (1948). Observations on sponges, including the supposed swarming of larvae, movement and coalescence in mature individuals, longevity and death. Proc. zool. Soc. Lond. 118: 893-915

Christensen, T. (1985). Microspora ficulinae, a green algae living in marine sponges. Br. Phycol. J. 20 (1): 5-7

Claus, G., Madri, P., Kunen, S. (1967). Removal of microbiol pollutants from waste effluents by the redbeard sponge. Nature, Lond. 216: 712-714

Coe, W. R. (1932). Season of attachment and rate of growth of sedentary marine organisms at the pier of the Scripps Institution of Oceanography, La Jolla, California. Bull. Scripps Inst. Oceanogr. tech. Ser. 3: 37-86

Coe, W. R., Allan, W. E. (1937). Growth of sedentary marine organisms on experimental blocks and plates for nine successive years at the pier of the Scripps Institution of Oceanography. Bull. Scripps Inst. Oceanogr. tech. Ser. 4: $101-130$

Dayton, P. K., Robilliard, G. A., Paine, R. T., Dayton, L. B. (1974). Biological accomodation in the benthic community at McMurdo Sound, Antarctica. Ecol. Monogr. 44: 105-128

Eimhjellen, K. E. (1967). Photosynthetic bacteria and carotenoids from a sea sponge Halichondrium panicea. Acta chem. scand. 21: 2280-2281

Elvin, D. W. (1976). Seasonal growth and reproduction of an intertidal sponge, Haliclona permollis (Bowerbank). Biol. Bull. mar. biol. Lab., Woods Hole 151: 108-125

Elvin, D. W. (1979). The relationship of seasonal changes in the biochemical components to the reproductive behaviour of the intertical sponge Haliclona permollis. Biol. Bull. mar. biol. Lab., Woods Hole 156: 47-61

Fell, P. E. (1967). Sponges. In: Wilt, F. H., Wessel, N. K. (ed.) Methods in developmentai biology. Crowell-Collier, New York, p. 265-276

Fell, P. E. (1974). Porifera. In: Giese, A. C., Pearse, J. S. (ed.) Reproduction of marine invertebrates, Vol. 1. Academic Press, New York, p. 51-132

Fell, P. E., Lewandrowski, K. B. (1981). Population dynamics of the estuarine sponge Halichondria sp. within a New England eelgrass community. J exp. mar. Biol. Ecol. 55: $49-63$

Ferguson, J. C. (1982). A comparative study of the net benefits derived from the uptake and release of free amino acids by marine invertebrates. Biol. Bull. mar. biol. Lab., Woods Hole 162: 1-17

Giese, A. C. (1966). Lipids in the economy of marine invertebrates. Physiol. Rev. 46: 244-298

Handel, E. van (1965). Estimation of glycogen in small amounts of tissue. Analyt. Biochem. 11: 256-265

Johnson, M. F. (1979). Recruitment, growth, mortality and seasonal variations in the calcareous sponges Clathrina coriacea (Montagu) and C blanca (M.-M.) from Santa Catalina Island, California. In: Lévi, C., Boury-Esnault, N (ed.) Biologie des spongiaires. Colloq. Internat. C.N.R.S Paris, 291: 325-334
Kilian, E. F. (1952). Wasserströmung und Nahrungsaufnahme beim Sußwasserschwamm Ephydatia fluviatilis. Z. vergl. Physiol. 34: 407-447

Kinne, O. (1977). Cultivation of animals: research cultivation. In: Kinne, O. (ed.) Marine ecology, Vol. III, Cultivation, Part 2. Wiley, Chichester, p. 579-1293

Lévi, C. (1956). Étude de Halisarca de Roscoff. Embryologie et systematique des Démosponges. Archs Zool. exp. gén. 93: $1-181$

Madri, P., Claus, G., Kunen, P., Moss, E. (1967). Preliminary studies on the Escherichia coli uptake of the redbeard sponge (Microciona prolifera, Verrill). Life Sci. 6: 889-894

Muscatine, L., Karakashian, S. J., Karakashian, M. W (1967). Soluble extracellular products of algae symbiotic with a ciliate, a sponge and a hydra. Comp. Biochem. Physiol. 20: $1-12$

Paine, R. T. (1964). Ash and calorie determinations of sponge and opistobranch tissues. Ecology 45 (2): 384-387

Pourbaix, N. (1931). Contribution à l'étude de la nutricion chez les Spongiaires (Ép. Siliceuses). Stn Ocean. Salammbo, Bull. 23

Pourbaix, N. (1932). Nota sobre la nutrición bacteriana de las esponjas. Publ. Inst. Esp. Ocean. Ser. II, Notas y resúmenes 64: 1-5

Pütter, A. (1914). Der Stoffwechsel der Kieselschwämme. Z. altg. Physiol. 16: 65-114

Rasmont, R. (1963). La role de la taille et de la nutricion dans le déterminisme de la gemmulation chez les Spongillides. Devl Biol. 8: 243-271

Reiswig. H. M. (1973). Population dymamics of three Jamaican demospongiae. Bull. mar. Sci. 23: 191-226

Remane, A. (1940). Einführung in die zoologische Ókologie der Nord- und Ostsee. Tierwelt Nord-u. Ostsee Ia

Schmidt, I. (1970). Phagocytose et pinocytose chez les Spongillidae. Z. vergl. Physiol. 66: 398-420

Smetacek, V., Bodungen, B. V., Knoppers, B., Peinert, R., Pollehne, F., Stegmann, P., Zeitzschel, B. (1984). Seasonal stages characterizing the annual cycle of an inshore pelagic system. Rapp. P.-v. Réun. Cons. int. Explor. Mer 183: $126-135$

Storr, J. F. (1976). Ecological factors controlling sponge distribution in the Gulf of Mexico and the resulting distribution. In: Harrison, F. W., Cowden, R. R. (ed.) Aspects of sponge biology. Academic Press, New York, San Francisco, London. p. 261-276

Theede, H. (1981). Studies on the role of benthic animals of the Western Baltic in the flow of energy and organic material. Kieler Meeresforsch. (Sonderh.) 5: 434-444

Weissenfels, N. (1976). Bau und Funktion des Süßwasserschwammes Ephydatia fluviatilis L. (Porifera). III. Nahrungsaufnahme, Verdauung und Defäkation. Zoomorph. 85: 73-88

Wells, H. W., Wells, M. J., Gray, I. E. (1964). Ecology of sponges in Hatteras Harbour, North Carolina. Ecology $54(4): 752-767$

Wilson, H. V (1935). Some critical points in the metamorphosis of the halichondrine sponge larva. J. Morph. 58, 285-345

Zöllner, N., Kirsch, K. (1962). Uber die quantitative Bestimmung von Lipoiden (Mikromethode) mittels der vieJen Lipoiden (allen bekannten Plasmalipoiden) gemeinsamen Sulpho-Phospho-Vanillin-Reaktion. Z. ges. exp. Med. 135: 545-561 